\title{
Taking steps with Confidence : Diponegoro University's Performance in the Midst of the Covid-19 Pandemic in 2020
}

\author{
Tri Handayani ${ }^{1 *}$, Yety Rochwulaningsih ${ }^{1}$, Singgih Tri Sulistiyono ${ }^{1}$ \\ ${ }^{1}$ Faculty of Humanities, Diponegoro University, Semarang - Indonesia
}

\begin{abstract}
Coronavirus disease 2019 (Covid-19) is a span-new pneumonia that is known to initially wide-spread from Wuhan city, the capital of Hubei Province, in the Mainland of China. This virus promptly dispersed around the world. In Indonesia, the first infection case took place in Depok, at the beginning of March of 2020. As a recent virus, Covid-19 did not yet have its antidote. The government rapidly acted on by implementing lockdown, as well as system preparation in order to get people working from home, as school and university students also learn from home. This policy was performed to cut the spread of Covid-19 virus. Various restrictions to limit social interaction has been highly impacting Indonesian citizen within the daily life. The restriction of direct interaction has also predisposed the implementation of tasks within the university setting. Diponegoro University-as an incorporated state university- follows the government regulation when it comes to proceed its tasks. Nearly all activities of the affected universities, namely administration service, assembly, learning service, research, and community service had changed due to the requirement to apply the health protocol. This paper focuses on how Diponegoro University confronted the Covid-19 pandemic, and how this college maintain its performance.
\end{abstract}

\section{Introduction}

Coronavirus Disease 2019 (COVID-19) was known for the first time, attacking the people of Wuhan City, the capital of Hubei Province, China, at the end of December 2019 and quoted from a journal article entitled "Coronavirus Disease 2019: Review of Current Literature" that the virus was known to spread quite rapidly to other people. The source quoted of the research states that there were five patients treated with an Acute Respiratory Distress Syndrome (ARDS) case from 18 to 29 December 2019. The case increased to 44 patients from 31 December 2019 to 3 January 2020. The terrible virus was unstoppable when in less than one month, it had infected people outside Hubei province in China, and even at that time, it had spread overseas, including in Thailand, Japan, and

\footnotetext{
* Corresponding author: tri.handayani@live.undip.ac.id
} 
South Korea [1-2]. One month later, this virus had infected more people in many countries. The news in online mass media published on 26 February 2020 showed the list of countries throughout the world infected by covid-19. According to the news, there were 37 countries infected by covid-19, namely: Afghanistan, Australia, Belgium, Bahrain, China, Hong Kong, Cambodia, Canada, Croatia, Macau, Egypt, Finland, France, Germany, India, Iran, Iraq, Israel, Italia, Japan, Kuwait, Lebanon, Malaysia, Nepal, Oman, Philippines, Russia, Singapore, South Korea, Spain, Sri Lanka, Sweden, Taiwan, Thailand, United Arab Emirates, United Kingdom, United States, Vietnam [3]. Not more than a month later, on Wednesday, 11 March 2020, Corona Virus Disease or Covid-19 had infected people in 114 countries with 118,000 (one hundred eighteen thousand) cases. On this basis, on that date/month/year, Covid-19 was defined as a global pandemic by the World Health Organization (WHO). Ir. Joko Widodo, as the President of the Republic of Indonesia, had announced the first case of an Indonesian citizen positively infected by covid-19 on Monday, 2 March 2020. It was also announced that the virus was transmitted between humans [1]. The report on covid-19 cases in the world on 21 January 2021 was 97,2 cases with a death toll of 2.08 million people [4]. Online mass media in Indonesia had also published the information from John Hopkins University (JHU) on the development of this case. This higher education institution, through Sputnik News, on 30 April 2021, released $150,068,372$ cases of covid-19 in the world with a death toll of $3,160,617$ people [5]. This virus was known to mutate. Mutated virus is commonly stronger than the previous one [6].

The World Health Organization is one of the bodies in the United Nations organization. This international organization has the objective of realizing maximum health degrees for all people in the world. This organization actively attempted to prevent contagious diseases. In addition, the organization also gives health assistance to countries in need, help mother and child health, help the implementation of many types of research in health throughout the world [7-8]. WHO had a hard time during the covid-19 pandemic in it initially spread to many parts of the world. The world society's challenge and opposition to WHO arose because of its delayed response to the cases. However, WHO still performed its duties just as the purpose assigned by the UN organization to it. [9].

The Government of the Republic of Indonesia had performed various measures to manage and prevent the spread of covid-19. One of the policies applied was to practice the work from home movement, washing hands using soap or disinfectant, wearing a mask, social distancing policies, forestalling crowd, limiting mobilization and physical interaction. [10].

This condition is a challenge for many Indonesian citizens because they get used to working in the field and in the office. Diponegoro University is one of the universities affected by the covid-19 case. In regards to this issue, this paper will examine how Diponegoro University can maintain its performance in the first year of the Covid-19 pandemic that hit the country of Indonesia.

\section{Method}

In this qualitative research, the data were collected through observation and secondary sources. The observation was conducted on the implementation of the policies made by the leader of Diponegoro University and this higher education institution's achievement in implementing its performance at the beginning covid-19 the pandemic struck Indonesia. This observation was conducted in line with the tracing of policies of the leader of Diponegoro University, policies implementation, and occurrences experienced by the society of Diponegoro University with the existing covid-19 case throughout 2020. The news was published through Diponegoro University's website. In addition, the data were also collected through literature study, covering journals of the result of researches related 
to covid-19, and the students' research results, guidelines published by the government in an effort to prevent and manage covid-19, mass media news, and supporting books. All of the data and (electronic) books were obtained through browsing on the internet [11]. After the data were collected, criticism was conducted on the various sources for conformity of the data to the research. Further, reconstruction was conducted so that an article was resulted entitled "Taking steps with confidence: Universitas Diponegoro's performance in the midst of the Covid-19 pandemic in 2020"

\section{Results and Discussion}

\subsection{About higher education performance}

Law of the Republic of Indonesia Number 12 the Year 2012 on Education defines Higher education as an educational unit organizing higher education. Higher Education has an obligation to implement the three pillars of higher education (known as tri dharma) consisting of education, research, and community service. These three duties are the difference between higher education with the primary and secondary education [12]. Higher education as an organization has various resources performing the higher education duties and functions. The higher education resources include human resources, facilities, knowledge, skills, government policies in various forms of permits to organize the higher education, funds, public supports [13]. In addition to these resources, higher education also has other resources, including local government supports to the higher education wherever it is located, local governments throughout Indonesia and local governments from abroad. Higher education also requires various resources in the form of supports from the industrial world communities both from home and foreign countries. Higher education also supports each other. Those supports are realized in collaboration between both parties. Higher education resources must be well managed with clear directions to achieve the predetermined goals as a higher education organization.

The main indicators of Public Higher Education in Indonesia as mentioned in the Guidance Book consist of : (1) The Graduates can get the proper jobs; (2) the students can get experiences outside of campus; (3) the lecturers can make various activities outside of campus; (4) the practitioners can teach at the campus; (5) the lecturers' working results can be used by the public or internationally recognized; (6) the study programs can collaborate with the world-class partners; (7) collaborative and participative classes; (8) the study programs has international standards [14].

\subsection{Regarding Covid-19}

Coronavirus is a type of virus. The term corona is derived from Old Greek "korōnè ", which means a bouquet of flowers. This term was first used in English in the 1500s "crown". Terence Chorba presented an illustration in his journal article of seven beams of light on the head of Helios (Dewa Matahari) of Greek Mythology. Meanwhile, Dado Antonius Sinaga states that the wall structure of the coronavirus has thorns or pikes around the cell, making its form look like a crown [15-17].

The disease caused by the coronavirus in the outbreak at the end of 2019 was called COVID-19 (coronavirus disease 2019) by WHO (World Health Organization). Meanwhile, the virus which causes the disease is called SARS-CoV-2 [17].

Virus of SARS-CoV-2 type has a long history. In 2002 there was a pandemic of coronavirus caused by the outbreak of coronavirus SARS-CoV or Severe Acute Respiratory Syndrome. In that year, the virus infected 8,000 people from 29 countries. 774 out of 8,000 
people were reported dead. The countries most affected by the virus were: Hong Kong, Canada, Singapore, Taiwan, China, and Vietnam. Later, in 2012 the virus MERS-CoV or Middle Ease Respiratory Syndrome infected Saudi Arabian citizens.

The spread of the Covid-19 virus initially was known to be through droplets from the mouth, nose and eyes. This virus was also known to be spread by individuals infected by a covid-19 virus that he/she touches items in his/their surroundings, such as door handle, phone, table, chair, etc. It can be imagined if the items are then touched by others, then they will have a high possibility of getting infected by the virus [17].

Individual whose body immune is by chance weak is known to be prone to infection of the covid-19 virus. Therefore, those who are frightened will have their body immune getting weakened. Those infected by this virus will feel their body having fever, dry cough, limp body, decreased appetite, and diarrhoea. Certain people also feel their senses of smell and taste not functioning. From the news and observation the researcher has conducted on surrounding people infected by this virus, the symptoms are not always the same from one another. Dado Antonius Sinaga states that the symptoms will appear 4-14 days after the virus gets into the body through the eyes, nose or mouth. This period is commonly called the period of incubation. An individual having the incubation period has not felt any of the symptoms of fever, dry cough, etc [17].

After some time, society is shocked by the finding of a new phenomenon, that individuals who look healthy may evidently get infected by the covid-19 virus. Individuals with this symptom are called Individuals without Symptom (OTG). OTG is very dangerous since those around them, and even the said people are not aware that they are reactive to covid-19 and may cause those around him/them to get infected by this virus [18-19].

In December 2020, the world was shocked by the appearance of new variants of the covid-19 virus. A new variant of the virus derived from the United Kingdom was known to have been detected in 60 countries. Meanwhile, on 20 January 2021, 10 other countries were reported to have an infection of the variant of the covid-19 virus from the United Kingdom. WHO predicted that the new virus variant was 50 to 70 per cent more contagious than the original virus. WHO, in its report on 19 January 2021, also stated that there was a new variant of the covid-19 virus from South Africa [18].

From the explanation above, it is known that covid-19 is a very dangerous virus when people are careless or even not concerned about their own and their environment's safety.

\subsection{Covid-19 Management in Indonesia by WHO}

WHO is one of the organizational bodies under the United Nations. This international organization was established on 7 April 1948. Currently, WHO has 7,000 people working in 150 countries, six regional offices, and a head office in Geneva. WHO has a relatively big role in various health issues faced by its members. Managing outbreaks is also part of its tasks, including the covid-19 outbreak. The task is one of the targets to be achieved by WHO of protecting all people in the world in the face of health emergencies [20-22].

WHO Indonesia is also one of the 150 offices of WHO besides its head office in Geneva. From the news published by the office of WHO Indonesia, it is known that some of WHO Indonesia's activities in support of the management and prevention of the spread of the covid-19 virus in this country are [23-24]:

1. WHO gives recommendations and leads in reviewing the plan for provincial countermeasures for all of the 34 provinces, facilitates coordination between central and provincial level.

2. WHO supports training of 500 health workers in preparing hospitals for new normal and 650 health workers for Covid-19 management at residential facilities for those prone for the last two weeks. 
3. WHO supports the government in procuring and distributing medical instruments and logistics with a total cost of 1.4 US Dollars.

4. WHO published important health messages regularly at WHO's website and social media platform, nine videos and 32 infographics have been translated in the last two weeks.

They are referring to the four supports from WHO for the Indonesian government and people in an effort to manage and prevent the spread of SARS-CoV-2, it is known that the health message entitled "Checklist to support schools re-opening and preparation for COVID-19 resurgences or similar public health crises" is the guidelines recommended by WHO to the Indonesian government for face-to-face learning implementation in the new normal era. The purpose of the checklist is to ensure that the people are compliant with the health protocol for students' health and safety while they are studying in the new normal era [25]. The recommendation is also followed by higher education institutions[26].

WHO gave a recommendation for employees to do their works in the new normal situation. This recommendation was published considering that employees were known to start off guard regarding the threat posed by SARS-CoV-2, which might attack them at any time when their body immune was weak [27-28].

WHO published a report on the information of the development of countries affected by covid-19. The information covered the total number of covid-19 cases, total number of covid-19 deaths, total number of patients recovering from covid-19, total number of those tested for covid-19. The report is open to the public. The key points of protection for employees in performing their duties, according to WHO and ILO, are as follows [27]:

1. Health workers should continue to enjoy their right to decent, healthy and safe working conditions in the context of COVID-19.

2. Primary prevention of COVID-19 among health workers should be based on risk assessment and introduction of appropriate measures.

3. Other occupational risks amplified by the COVID-19 pandemic, including violence, harassment, stigma, discrimination, heavy workload and prolonged use of personal protective equipment (PPE) should be addressed.

4. Occupational health services, mental health and psychosocial support, adequate sanitation, hygiene and rest facilities should be provided to all health workers.

5. Health-care facilities should have occupational health programs in conjunction with programs for infection prevention and control.

6. Employers have the overall responsibility to ensure that all necessary preventive and protective measures are taken to minimize occupational risks to health workers.

7. Health workers are responsible for following established rules for the protection of their health and safety at work.

Principally, WHO gave recommendations to the government and the society throughout the world regarding the importance of keeping health protocol so that covid-19 will be solved immediately. The government and the society need to move simultaneously, work together to solve this pandemic. Such a commitment does not only apply to the people of one country but also between countries. In case a country finds difficulty, other countries, if their condition allows it, is to help it [29]. 


\subsection{Covid-19 Managed by the Government of the Republic of Indonesia}

COVID-19 was first reported in Indonesia on 2 March 2020 of two cases [1]. The data of 31 March 2020 show confirmed 1,528 cases and 136 death cases [30]. The government immediately formed the COVID-19 Response Acceleration, Task Force. The Task Force was strengthened with the Presidential Decree of the Republic of Indonesia Number 7 of 2020 concerning the Corona Virus Disease 2019 (COVID-2019) Response Acceleration Task Force. According to article 2 of the Presidential Decree, the COVID-19 Response Acceleration Task Force was under and responsible to the President. Further, article 3 regulates the purposes of formation of the COVID-19 Response Acceleration Task Force, namely:

a. Improve the national resilience in health sector;

b. Accelerate COVID-19 response through synergy between ministries/agencies and regional government;

c. Improve anticipation of development of COVID-19 spread escalation;

d. Improve synergy of operational policy making; and

e. Improve preparation and ability in preventing, detecting and responding to COVID$19[1,31]$.

Furthermore, Presidential Decree of the Republic of Indonesia Number 7 of 2020 concerning Corona Virus Disease 2019 (COVID-2019) Response Acceleration Task Force also regulates the provisions of organizational matters. The provisions can be found in article 5 and article 6 as follows:

Article 5, Director of COVID-19 Response Acceleration Task Force as referred to in Article 4 item a has the following tasks:

a. Give direction to Executor in implementing COVID-19 response acceleration; and

b. Monitor and evaluate implementing COVID-19 response acceleration.

Article 6, Executor of COVID-19 Response Acceleration Task Force as referred to in Article 4 item $b$ has the following tasks:

a. Set and implement operational plan for COVID-19 response acceleration;

b. Coordinate and control the implementation of COVID-I9 response acceleration activities;

c. Supervise the implementation of COVID-19 response acceleration;

d. Deploy resources for the implementation of COVID-19 response acceleration activities; and

e. report COVID-19 response acceleration to the President and Director.

Furthermore, Article 7 regulates the following provisions:

(1) Performing its tasks, the COVID-19 Response Acceleration Task Force is assisted by a Secretariat domiciled at the Indonesian National Board for Disaster Management.

(2) Secretariat as referred to in paragraph (1) is assigned to give technical and administrative supports to the COVID-19 Response Acceleration Task Force.

Although covid-19 is a national disaster-related to health, however, the COVID-19 Response Acceleration Task Force consists of inter-sectoral elements which are related to disaster matters. This may be found from the elements involved in the Task Force, as may be observed in article 8 below:

Article 8, The membership structure of COVID-19 Response Acceleration Task Force consists of:
A. Director:
1. Coordinating Minister for Human Development and Cultural Affairs;
2. Coordinating Minister for Political, Legal, and Security Affairs; 
3. Minister of Health; and

4. Minister of Finance.

B. Executor

Chairman: Head of the Indonesian National Board for Disaster Management Vice Chairmen:

1. Assistant Operation Commander of Indonesian National Armed Force; and

2. Assistant Operation Chief of Indonesian National Police.

Members:

1. Element of Coordinating Minister for Human Development and Cultural Affairs;

2. Element of Ministry of Health;

3. Element of Ministry of Home Affairs;

4. Element of Ministry of Foreign Affairs;

5. Element of Ministry of Transportation;

6. Element of Ministry of Communication and Information;

7. Element of Ministry of Education and Culture;

8. Element of Ministry of Agama;

9. Element of Indonesian National Board for Disaster Management;

10. Element of Indonesian National Armed Force;

11. Element of Indonesian National Police; and

12. Element of Presidential Staff Office.

This Task Force performs its tasks as set forth in article 10 through article 13 of the Presidential Decree.

In its development, covid-19 was evidently widespread and had impacts on the social, economic, health and welfare aspects of the Indonesians. In addition, on 11 March 2020, also stated that COVID-19 was a Global Pandemic. Therefore, Presidential Decree of Republic of Indonesia Number 7 of 2020 concerning the Corona Virus Disease 2019 (COVID-2019) Response Acceleration Task Force was then amended by the Presidential Decree of the Republic of Indonesia Number 9 of 2020 concerning the Amendment to Presidential Decree Number 7 of 2020 concerning Corona Virus Disease 2019 (COVID-19) Response Acceleration Task Force. Some articles were amended, especially article 8 . The elements involved in the Task Force were added so that the Task Force would be stronger with support from various sectors, from Central to Local levels. The new formation of the Task Force is quite effective considering that the Republic of Indonesia is quite wide, consisting of thousands of islands and a total population of 271,349,889 people [29].

The Corona Virus Disease 2019 (COVID-19) Response Acceleration Task Force implemented its tasks based on the COVID-19 (Corona Virus Disease 2019) PANDEMIC RESPONSE ACCELERATION PROTOCOL [1]. In addition, the government, through related ministries, issued guidelines as the direction for activities for the people amidst the covid-19 pandemic. One of the guidelines was the Guidelines on Covid-19 Prevention and Management at Work Place. The guidelines were the result of cooperation of the International Labor Organization, the Indonesian Medical Association for Occupational Health (IDKI) and the Ministry of Labor Affairs of the Republic of Indonesia. The issuance of the guidelines was funded by UNAIDS in 2020 [33].

\subsection{Covid-18 Management in Diponegoro University Environment}

Diponegoro University is one of the leading state higher education institutions in Indonesia. Diponegoro University is also affected by the covid-19 pandemic. As commonly known, with the continuous spreading of the covid-19 outbreak, the government issued Government Regulation of the Republic of Indonesia Number 21 of 2020 concerning Large 
Scale Social Distancing (PSBB). This policy was issued in an effort to accelerate the covid19 outbreak response. With the policy, government administrators could perform any measures of their policies with the approval of the Minister of Health.

Diponegoro University, like other higher education institutions, also applied PSBB for two weeks while preparing the academic system and other systems so that the learning process could continue online, while its staffs were also prepared for their working system so that the administrative services could continue amidst the implementation of PSBB policy with provisions as stipulated through Circular of Rector of UNDIP [34-35]. The covid-19 pandemic was a priceless experience for Diponegoro University, especially in the early period of pandemic throughout the world in 2020. For this reason, this research was intended specifically to discuss how Diponegoro University could survive in the covid-19 pandemic in 2020.

The Rector of the University immediately issued Circular of Rector of UNDIP Number 9/UN7.P/SE/2020 concerning Virus Corona (Covid-19) response. Furthermore, the Rector issued explanatory note to the Circular in Circular of Rector of UNDIP Number 14/UN7.P/SE/2020. The matters regulated in the Circular are [36]:

1. All activities involving visit, either from or to other countries, within the time determined in the circular until 30 June 2020 are cancelled, while activities after 30 June 2020 will wait for the development.

2. Inhabitants of Diponegoro University campus who are going overseas, the decision of departing or waiting is a personal decision and responsibility.

3. Inhabitants of Diponegoro University campus who just arrive from overseas must immediately report to the Office of International Affairs, Rector Office of Diponegoro University at Gedung Widya Puraya through link: http://tiny.cc/incomingreport-Undip RSND for recording and examination processes at Diponegoro National hospital and then not perform any activity in the environment of Diponegoro University or participate in any activities in Diponegoro University for 14 days.

4. All leaders in the environment of Diponegoro University must ensure that those in point 3 (three) have reported through the link above.

The policy was implemented well. Lecturers and education staff did not make any official trip. Lecturers and education staff who happened to just arrive from overseas for official activities and religious activities must perform self-isolation at home for 14 days. These policies were then followed by subsequent policies in adaptation to the very dynamic situation. Agus Joko Mulyono, in his report for Tagar.id stated there were 14 policies of Diponegoro University in an effort to prevent the spread of virus corona. The policies were expressed in Circular of Rector Number 20/UN.7.P/SE/2020 dated 14 March 2020. The 14 policies are [37-38]:

1. Courses and guiding scheduled from 16-21 March 2020 are postponed and will be implemented in other time.

2. On those dates, it is unnecessary for students to be at campus, while personnel administration will operate as usual.

3. Courses and guiding activities after 21 March 2020 are to be implemented online.

4. The courses and guiding activities are implemented online until the end of semester I or until a certain time, in observance of the existing condition.

5. The online courses and guiding or assistance activity pattern is optional, which means it can be conducted in various forms pursuant to prevailing principle in consideration of learning outcome.

6. Faculty leaders determine the form of practical course while still referring to avoidance of face-to-face meeting. In case this is unavoidable, Covid-19 spread mitigation and prevention must be made.

7. Faculty leaders must ensure successful courses and guiding online. 
8. Unit leaders must prepare, perform anything needed to support Covid-19 spread prevention efforts.

9. The implementation of graduation ceremony for semester I is also postponed, while educational credentials and academic transcript can be taken by students at determined time.

10. All students' activities which may potentially lead to mass gathering, both in and out of campus area, are postponed and cancelled until appropriate condition.

11. Research and society service activities are implemented in consideration of covid-19 spread prevention efforts.

12. It is recommended to postpone or cancel all official trips of Undip employees.

13. It is recommended to postpone or cancel all students' trips with regard to student affairs activities.

14. All society of academicians of Undip are to keep the environment conducive and must actively participate in prevention of Covid-19 spread.

With the policy, any field learning activities are postponed for an undetermined time limit. Students of History Department of Academic Year 2018 who are currently preparing for Job Training are to cancel the activity. They must accept it even if any costs have been paid, including for transportation.

With the covid-19 outbreak, during even semester of 2019/2020 and odd semester of 2020/2021, all learning activities are performed online. All of research activities, society service activities, and supporting activities are performed in consideration of covid-19 spread prevention efforts. The most outstanding in 2020 was online learning; final project, thesis, and dissertation guidance activities are performed online. These activities were initially quite burdensome since lecturers and students must have sufficient quota. In further development, quota aid was given to students. Researches were online document based, and students performed KKN activities in their respective area under strict health protocol. Graduation ceremony was conducted online, and webinar activities are quite more common. The Central Government, Local Governments, Budiness Entities, Civil Society Organization, communities, and Departments of higher education institutions organized webinar. We can even say that there is no day without webinar.

The policies of the Rector of Undip related to the efforts to prevent the spread of covid19 are through the website of Diponegoro University in 2020 as follows:

1) Circular of Rector Number 9 of 2020 concerning Dealing with Corona Virus

2) Circular of Rector Number 14 of 2020 concerning Follow-up of Dealing with Corona

3) Circular of Rector Number 20 of 2020 concerning Course Activities in Corona Pandemic

4) Circular of Rector Number 21 of 2020 concerning Scheduling of Employee Working Hour in Prevention of the Spread of Corona

5) Circular of Rector Number 22 of 2020 concerning the Second Scheduling of Employee Working Hour in Prevention of the Spread of Corona

6) Circular of Rector Number 23 of 2020 concerning Learning and Teaching Process during Covid-19 Pandemic

7) Circular of Rector Number 34 of 2020 concerning Change to National Holidays and Collective Leave in 2020

Meanwhile, various policies were issued, one of which was to alleviate student's burden. Besides policies, there were also aids from CSR and alumni. The aids include: relief in UKT payment [39], quota aid [40], basic needs aid and/or money for students from Indonesia and students affected by PSBB, forcing them to stay in Semarang City during Eid al-Fitr Holiday $1441 \mathrm{H}[41]$. 


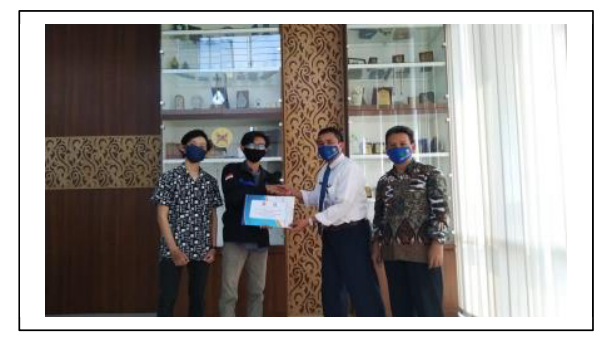

Fig 1. Students of Engineering Faculty receiving quota aid from PT. Adhi Karya.

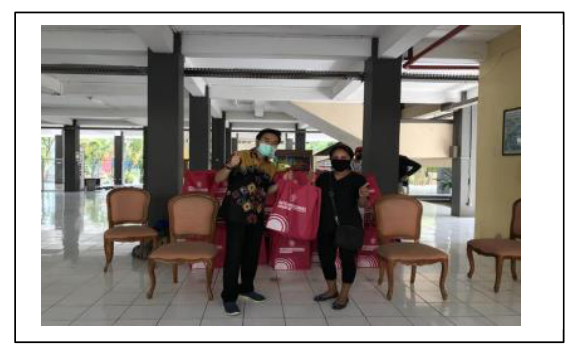

Fig 2. Foreign Students taking basic needs aid at the Office of International Affairs, Universitas Diponegoro.

Besides the activities above, in 2020, Undip also performed social activities out of the campus, including IKA Undip Gandang JNE Distributed Aid for Social Service in the 63rd Dies of Undip [42]. Students of UNDIP Created Mbantu Tonggo Application [43], Robots SEBEMOT and SEBEVIMOT the work of UNDIP was ready to help services by Government of Semarang City [44], Undip was in synergy with the Government of Semarang City in Covid-19 response [45], and other activities which were principally related to covid-19 spread prevention efforts.

Students of Undip in 2020 could still excel despite their limited movement because of the covid-19 outbreak, such as:

1) Astri Ayu Nastiti (Faculty of Science and Mathematics) as the first winner of Doctor of Data 2020 of Diponegoro University (14-15 November 2020)

2) Ali Mahmudan (Faculty of Science and Mathematics) as the first winner of LKTIN MATRIKS 2020 University of Muhammadiyyah Malang (13-15 March 2020) and the first winner of Infographic Competition of Doctor of Data 2020 of Diponegoro University (14-15 November 2020)

And there are many other students of Diponegoro University who have many achievements at the national level during 2020.

Diponegoro University as a higher education organization also received various achievements at both national and international levels during 2020 as follows.

1) The $4^{\text {th }}$ Best University in Indonesia according to UniRank version announced on 19 February 2020 [46]. This achievement went up to the $3^{\text {rd }}$ rank published on February 22, 2021 [47].

2) Top 9 Best University in Indonesia According to The World University Rankings 2021 published on 10 September 2020 [48].

3) The Second Best National Green Campus according to the Version of UI GreenMetric 2020 published on 12 December 2020 [49].

4) The World's Top 200 according to THE Impact Rankings 2021 published on 23 April 2021 [50]. 


\section{Conclusion}

Based on the explanation above, we may conclude that Diponegoro University, as an autonomous state higher education institution, has the heavy responsibility for maintaining the survival of campus life during the covid-19 outbreak throughout the world. Throughout 2020, it was known that this higher education institution, despite the covid-19 impacts, remained operating its performance well, and even its students and Diponegoro University as a higher education organization could still excel.

In this change, the writer would like to say thanks to DIRSIMLITABMAS for its support and DPRM funding for the writer's doctoral funding within two years (2020-2021). This manuscript is one of the parts of the writer's doctoral funding. The author is beholden to Prof. Dr Yety Rochwulaningsih, M.Si. and Prof. Dr Singgih Tri Sulistiyono, M.Hum. as the dissertation supervisor team, as well as their supports towards attaining research grant within the doctoral program.

\section{References}

1. Gugus Tugas Percepatan Penanganan COVID-19, Protokol percepatan penanganan pandemic Covid-19 (Corona Virus Disease 2019), (2019)

2. C. A. Susilo, M. Rumende, C. W. Pitoyo, W. D. Santoso, M. Yulianti, Herikurniawan, R. Sinto, G. Singh, L. Nainggolan, E. J. Nelwan, L. K. Chen, A. Widhani, E. Wijaya, B. Wicaksana, M. Maksum, F. Annisa, C. O. M. Jasirwan, E. Yunihastuti, Coronavirus disease 2019: review of current literatures, J. Penyakit Dalam Indonesia, 7, 1 (2020)

3. F. S. Agiesta, (February, 2020), Ini daftar lengkap negara-negara di dunia yang sudah dimasuki virus corona, Retrieved from https://www.merdeka.com/dunia/inidaftar-lengkap-negara-negara-di-dunia-yang-sudah-dimasuki-virus-corona.html

4. G. S. Putri, (January, 2021), Kasus Covid-19 RI nyaris 1 juta, kenali 4 cara penularan virus corona, Retrieved from https://kesehatan.kontan.co.id/news/kasus-covid-19-rinyaris-1-juta-kenali-4-cara-penularan-virus-corona?page $=$ all

5. F. Wulandari, (April, 2021), Jumlah kasus Covid-19 di seluruh dunia melampaui 150 juta, Retrieved from https://www.tribunnews.com/corona/2021/04/30/jumlah-kasuscovid-19-di-seluruh-dunia-melampaui-150-Juta

6. Ika, (May, 2020), Virus corona terus bermutasi jadi tantangan pengembangan vaksin. Retrieved from https://www.ugm.ac.id/id/berita/19453-virus-corona-terus-bermutasijadi-tantangan-pengembangan-vaksin

7. P. Y. Silitonga, Peranan WHO sebagai subjek hukum internasional dalam peccegah penyebaran Covid-19. Skripsi tidak diterbitkan pada Departemen Hukum Internasional Fakultas Hukum Universitas Sumatera Utara (2020)

8. R. H. Permana, (April, 2020), Kontroversi Respons WHO Atas Pandemi Corona yang Dinilai Terlambat, Retrieved from https:/news.detik.com/internasional/d4987825/kontroversi-respons-who-atas-pandemi-corona-yang-dinilai-terlambat/1

9. IFRC, WHO, UNICEF, Pelayanan kesehatan berbasis komunitas, termasuk penjangkauan dan kampanye, dalam konteks pandemi COVID-19, Panduan interim, (2020)

10. Kementrian Luar Negeri, (February, 2020), Langkah dan upaya Pemerintah Indonesia dalam menangani dan menghadapi virus novel corona 2019 (N-COV), Retrieved from https://kemlu.go.id/pretoria/id/news/4771/langkah-dan-upaya-pemerintah-indonesiadalam-menangani-dan-menghadapi-virus-novel-corona-2019-n-cov.published 
11. J. W. Creswell, Research design: pendekatan metode kualitatif, kuantitatif, dan campuran, (2017)

12. S. Abbas, Manajemen perguruan tinggi, (2008)

13. M. F. Amir, Manajemen kinerja perguruan tinggi, (2016)

14. Direktorat Jenderal Pendidikan Tinggi Kementerian Pendidikan dan Kebudayaan, Buku Panduan Indikator Kinerja Utama Perguruan Tinggi Negeri, (2020)

15. L. M. Sauer, M. S. Reviewer, (May, 2021), What is Coronavirus, Retrieved from https://www.hopkinsmedicine.org/health/conditions-and-diseases/coronavirus

16. T. Chorba, The Concept of the crown and its potential role in the downfall of coronavirus, J. Emerging Infectius Diseases, 26, 9 (2020)

17. D. A. Sinaga, (May, 2020), Virus corona: hal-hal apa yang perlu diketahui, Retrieved from http://www.inaheart.org/news_and_events/news/2020/5/13/virus_corona halhal apa yang perlu diketahui

18. WHO, Transmisi SARS-Cov-2: implikasi terhadap kewaspadaan pencegahan infeksi, (2020)

19. P. Kurniati, (December, 2020), Berawal jenguk saudara 18 orang sekeluarga positif covid 19, 2 orang meninggal, Retrieved from https://regional.kompas.com/read/2020/12/20/13030911/berawal-jenguk-saudara-18orang-sekeluarga-positif-covid-19-2-meninggal?page $=$ all

20. N. F. Shalihah, (January, 2021), 60 negara melaporkan strain baru virus corona Inggris, bagaimana dengan Indonesia, Retrieved from https://www.kompas.com/tren/read/2021/01/21/092000965/60-negara-melaporkanstrain-baru-virus-corona-inggris-bagaimana-dengan

21. WHO, What we do, Retrieved from https://www.who.int/about/what-we-do

22. D. Noviyanti, (February, 2021), Peran penting WHO sebagai organisasi kesehatan dunia dalam menangani pandemi, Retrieved from https://kumparan.com/debynoviyanti/peran-penting-who-sebagai-organisasi-kesehatan-dunia-dalam-menanganipandemi-1vBya1xHEm5

23. WHO Indonesia, Coronavirus disease 2019 (COVID-19) ikhtisar kegiatan - 2, (2020)

24. H. Widowati, (February, 2020), WHO siapkan respons penanganan virus corona senilai Rp9,22 trilliun, Retrieved from https://katadata.co.id/hariwidowati/berita/5e9a495da4b99/who-siapkan-responspenanganan-virus-corona-senilai-rp-922-triliun

25. WHO, Checklist to support schools re-opening and preparation for COVID-19 resurgences or similar public health crises, (2020)

26. R. Wijaya, (December, 2020), Kuliah tatap muka tergantung rekomendasi satgas covid-19, Retrieved from https://rri.co.id/semarang/pendidikan/seputarpendidikan/945528/kuliah-tatap-muka-tergantung-rekomendasi-satgas-covid-19

27. WHO and ILO, (May, 2021), Preventing and mitihating COVID-19 at work, Retrieved from https://www.who.int/publications/i/item/WHO-2019-nCoVworkplace-actions-policy-brief-2021-1

28. WHO and ILO, COVID-19 : occupational health and safety for health workers, Interim Guidance, (2021)

29. WHO, (April, 2020), Coronavirus disease 2019 (COVID-19) Situation Report - 94, Retrieved from https://www.who.int/docs/default-source/coronaviruse/situationreports/20200423-sitrep-94-covid-19.pdf

30. R. S. Nugroho, (March, 2020), Rekap kasus corona Indonesia selama maret dan prediksi di bulan april, from https://www.kompas.com/tren/read/2020/03/31/213418865/rekap-kasus-coronaindonesia-selama-maret-dan-prediksi-di-bulan-april?page=all 
31. Tim detikcom, (May, 2021), Perjalanan doni monardo 2 tahun jabat kepala BNPB, Retrieved from https://news.detik.com/berita/d-5581535/perjalanan-doni-monardo-2tahun-jabat-kepala-bnpb

32. M. Idris, (January, 2021), 7 provinsi dengan jumlah penduduk terbanyak di Indonesia, Retrieved from https://money.kompas.com/read/2021/01/24/090600726/7-provinsidengan-jumlah-penduduk-terbanyak-di-

Indonesia?page=all\#: : text=Data $\% 20$ tersebut $\% 20$ disusun $\% 20$ dari $\% 20$ Sensus, (jumlah \%20penduduk\%20Indonesia\%202021).published

33. ILO, Pedoman pencegahan dan penanggulangan covid-19 di tempat kerja, (2020)

34. N. R. Yunus, Kebijakan pemberlakuan lock down sebagai antisipasi penyebaran corona virus covid-19, J. Salam, 7, 3 (2020)

35. A. Ristyawati, Efektifitas kebijakan pembatasan sosial berskala besar dalam masa pandemi corona virus 2019 oleh pemerintah sesuai amanat UUD NRI tahun 1945, J. Administrative Law \& Governance Journal, 3, 2 (2020)

36. Universitas Diponegoro, (March, 2020), Penjelasan SE rektor penanggulangan virus corona (covid-19)", Retrieved from https://www.undip.ac.id/post/14949/penjelasanse-rektor-penanggulangan-virus-corona-covid-19.html

37. Universitas Diponegoro, (March, 2020), Upaya pencegahan virus corona (covid-19), Retrieved from https:/www.undip.ac.id/post/14952/upaya-pencegahan-virus-coronacovid-19-di-lingkungan-undip.html

38. A. J. Mulyono, (March, 2020), 14 kebijakan undip semarang cegah penyebaran corona, Retrieved from https://www.tagar.id/14-kebijakan-undip-semarang-cegahpenyebaran-corona

39. Universitas Diponegoro, (July, 2020), Undip terapkan kebijakan UKT berbasis kepedulian: respon terhadap pandemi covid-19, https://www.undip.ac.id/post/15876/undip-terapkan-kebijakan-ukt-berbasis-

kepedulian-respon-terhadap-pandemi-covid-19.html

40. Universitas Diponegoro, (July, 2002), PT. Adhi Karya turut berikan bantuan kuota internet Rp150 juta untuk mahasiswa FT Undip,

Retrieved from https://www.undip.ac.id/post/15612/pt-adhi-karya-turut-berikanbantuan-kuota-internet-rp-150-juta-untuk-mahasiswa-ft-undip.html

41. Universitas Diponegoro, (June, 2020), UNDIP kembali bagikan sembako untuk mahasiswa asing, Retrieved from https://www.undip.ac.id/post/15493/undip-kembalibagikan-sembako-untuk-mahasiswa-asing.html

42. Universitas Diponegoro, (September, 2020), Ika undip gandeng JNE distribusikan bantuan untuk baksos dies Ke-63 Undip, Retrieved from https://www.undip.ac.id/post/16528/ika-undip-gandeng-jne-distribusikan-bantuanuntuk-baksos-dies-ke-63-undip.html

43. Universitas Diponegoro, (September, 2020), Mahasiswa UNDIP ciptakan aplikasi mbantu tonggo, Retrieved from https://www.undip.ac.id/post/16464/mahasiswaundip-ciptakan-apilkasi-mbantu-tonggo.html

44. Universitas Diponegoro, (September, 2020), SEBEMOT dan SEBEVIMOT, robot karya UNDIP siap membantu pelayanan Pemkot Semarang, Retrieved from https://www.undip.ac.id/post/16424/sebemot-dan-sebevimot-robot-karya-undip-siapmembantu-pelayanan-pemkot-semarang.html

45. Universitas Diponegoro, (September, 2020), Sinergi UNDIP dan Pemkot Semarang dalam penanganan covid-19, Retrieved from https://www.undip.ac.id/post/16421/sinergi-undip-dan-pemkot-semarang-dalampenanganan-covid-19.html

46. Universitas Diponegoro, (February, 2020), Undip menempati urutan perguruan tinggi terbaik ke-4 di Indonesia versi unirank (4ICU.org) tahun 2020, Retrieved from 
https://www.undip.ac.id/post/13859/undip-menempati-urutan-perguruan-tinggiterbaik-ke-4-di-indonesia-versi-unirank-4icu-org-tahun-2020.html

47. Universitas Diponegoro, (February, 2021), Peringkat UNDIP di unirank membaik jadi 3 besar di tahun 2021, Retrieved from https://www.undip.ac.id/post/17664/peringkatundip-di-unirank-membaik-jadi-3-besar-di-tahun-2021.html

48. Universitas Diponegoro, (September, 2020), 9 besar universitas terbaik di Indonesia menurut the world university rankings 2021, Retrieved from

https://www.undip.ac.id/post/16348/undip-masuk-9-besar-universitas-terbaik-diindonesia-menurut-the-world-university-rankings-2021.html

49. A. Iffana, (December, 2020), UNDIP raih peringkat ke dua terbaik nasional kampus hijau versi UI greenmetric 2020, Retrieved from https://www.ikaundip.org/readmore/75979-undip-raih-terbaik-ii-ui-greenmetricindonesia-2020

50. Kompas.com, (April, 2021), Undip masuk posisi 200 terbaik dunia di the impact rankings 2021, Retrieved from https://www.kompas.com/edu/read/2021/04/23/161006871/undipmasuk-posisi-200-terbaik-dunia-di-the-impact-rankings-2021?page=all 